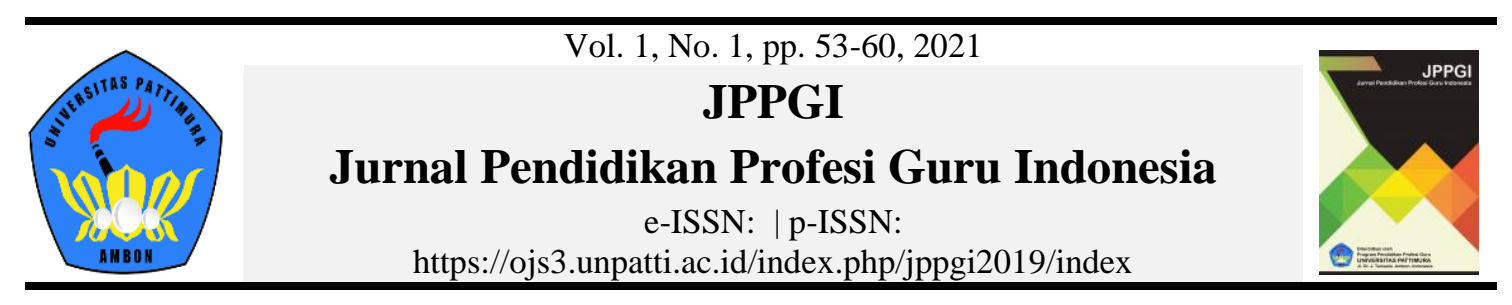

\title{
Analisis Strategi Pembelajaran Ekspositori pada Guru IPS
}

\begin{abstract}
Stevie Sahusilawane
Program Studi Pendidikan Ekonomi, Fakultas Keguruan dan Ilmu Pendidikan, Universitas PattimuraAmbon, Indonesia

*Corresponding e-mail: steviesahusilawane@gmail.com

Received: 12 September 2020

Accepted: 10 December 2020

Online Published: 08 February 2021

Abstract: Tujuan dari penelitian ini adalah untuk mengetahui strategi pembelajaran ekspositori pada guru IPS di SMP Negeri 9 Leihiutu Satap. Penelitian dilakukan dengan menggunakan metode deskriptif untuk menggambarkan kejadian atau peristiwa pada saat pembelajaran berlangsung. Hasil penelitian menunjukan bahwa dalam proses pembelajaran ekspositori ada lima tahapan yang digunakan oleh guru dalam proses pembelajaran berupa persiapan, penyajian, korelasi, penyimpulan dan pengaplikasian. Di dalam tahapan tersebut pelaksanaan pembelajaran dengan strategi ekspositori pada guru sudah sesuai dengan perencanaan serta terlaksana dengan baik. Hal ini dapat terlihat bahwa siswa telah memahami materi dan mampu menjawab pertanyaan-pertanyaan guru dengan baik. Dapat disimpulkan bahwa penggunakan strategi ekspositori pada guru IPS sudah terlaksana dengan baik.
\end{abstract}

Kata kunci: Strategi pembelajaran, Ekspositori, Guru IPS

To cite this article:

Sahusilawane, S. (2021). Analisis strategi pembelajaran ekspositori pada guru ips. JPPGI: Jurnal Pendidikan Profesi Guru Indonesia, 1(1), 53-60.

\section{PENDAHULUAN}

Pendidikan merupakan salah satu mesin penggerak kelangsungan hidup suatu bangsa (Cenoz, 2012), karena pendidikan dapat mengembangkan kualitas sumber daya manusia yang cakap dan berdaya saing tinggi secara regional maupun global (Hammond, 2016). Selain itu, pendidikan mempunyai arti yang sangat penting, yakni mampu meningkatkan ekonomi dari kemiskinan masyarakat (Ferguson, Bovaird, \& Mueller, 2007). Oleh karena itu pendidikan harus dilaksanakan dengan sebaik mungkin. Pendidikan yang diselenggarakan oleh pemerintah melalui sekolah merupakan lembaga yang bertanggung jawab atas keberhasilan peserta didik di masa depan (Darlinghammond et al., 2019).

Kurikulum saat ini dituntut untuk menjadikan peserta didik mampu mengembangkan pengetahuan dan keterampilan sesuai dengan standar yang ditetapkan dan menintegrasikan kecakapan hidup (Genlott \& Grönlund, 2013). Guru bertindak sebagai fasilitator, motivator, dan mediator yang membantu agar proses pembelajaran dapat tercapai (Ellerani \& Gentile, 2013). Komponen yang menjadi perhatian guru dalam sebuah pembelajaran adalah hasil belajar kognitif, afektif dan psikomotorik siswa (Post, Guo, Saab, \& Admiraal, 2019). Pada dasarnya dalam suatu proses pembelajaran merupakan proses komunikasi yang terdiri dari guru, peserta didik, materi 
pembelajaran, dan strategi yang dipakai dalam proses pembelajaran tersebut.

Belajar merupakan suatu proses perubahan yang berlangsung relatif lama melalui simulasi dan pengalaman yang membawa kepada perubahan diri peserta didik secara kontemporer (Schaap, Baartman, \& de Bruijn, 2012). Para ahli yang lainnya menjelaskan secara eksplisit bahwa pembelajaran sebagai kegiatan yang disampaikan secara terstruktur dan teratur dengan menggunakan berbagai ide yang orginal dalam mengembangkan kreativitas berpikir peserta didik (Ritter \& Mostert, 2017). Proses pembelajaran memiliki tujuan agar siswa dapat mencapai kompetensi akademik dan sosial yang baik (Schneider \& Sparfeldt, 2020). Tugas guru adalah mampu memberikan kemudahan belajar pada siswa untuk mencapai tujuan pembelajaran (Leung \& Wang, 2006). Tapi semua ini tidak sejalan dengan harapan yang ditemukan dilapangan. Hal ini dibuktikan dengan kompetensi guru yang relatif rendah. Data menginformasikan bahwa 17\% sampai $19 \%$ lulusan LPTK yang mengajar tidak sesuai dengan bidang keahliannya. Selain itu 29\% guru masih berstatus non sarjana (Sukanti, Sumarsih, Siswanto, \& Widayati, 2008). Oleh karena itu berbagai upaya pemerintah dilakukan berupa peningkatan profesionalisme guru melalui Program Pendidikan Profesi Guru (PPG) untuk menghasilkan SDM yang unggul untuk mengubah wajah pendidikan di Indonesia.

Pada kurikulum Sekolah Menengah Pertama (SMP) mata pelajaran IPS merupakan bidang studi terpadu yang dibelajarkan kepada siswa. Namun, seringkali guru dihadapkan dengan berbagai permasalahan dalam pembelajaran. Salah satunya yaitu kurangnya motivasi belajar siswa (Gbollie \& Keamu, 2017). Hal ini karena pembelajaran lebih diarahkan untuk menghafal sehingga merasa bosan dalam belajar. Guru berlaku sebagai pusat pembelajaran dan cenderung lebih aktif sebagai pemberi informasi dan menjelaskan materi sejelas-jelasnya, sehingga siswa cenderung pasif, malu, dan takut untuk bertanya walaupun mengalami kesulitan dalam pembelajaran materi yang diberikan. Guru harus memberikan ruang kepada siswa untuk berekspresi untuk menemukan konsep yang baru. Dengan demikian guru harus sedapat mungkin berusaha menggunakan strategi pembelajaran yang tepat untuk menciptakan suasana belajar yang terbuka dan menyenangkan dalam berinovasi.

Mengatasi permasalahan yang ada, maka penggunaan strategi yang tepat akan membangkitkan aktivitas peserta didik mampu untuk menyerap materi diberikan dan memberikan kesan menyenangkan dalam pembelajaran. Oleh sebab itu, guru dituntut harus lebih kreatif dalam menyikapi dan merancang strategi pembelajaran yang sesuai dengan kondisi belajar. Langkah selanjutnya untuk meningkatkan pemahaman konsep siswa guru meningkatkan interaksi antara guru dan siswa. Hal ini sangat penting sehingga mereka dapat saling membantu. Artinya seorang guru harus lebih banyak memberi bantuan dan dorongan, serta pengawasan atau binaan. Setelah langkah-langkah tersebut dilakukan oleh guru, ditemukan lagi fenomena baru yakni, ada siswa yang memiliki pikiran yang kreatif namun kurang berani mengungkapkan gagasan atau pendapatnya di kelas. Berdasarkan fenomena tersebut maka seorang guru, untuk mencapai tujuan keberhasilan mengajar tidak lepas dari beberapa faktor penunjang diantaranya adalah kondusifnya lingkungan belajar dan kualitas seorang guru itu sendiri.

Strategi pembelajaran yang direkomendasikan adalah strategi pembelajaran ekspositori yang berpusat pada siswa. Pengorganisasiannya dapat dilakukan secara berkelompok, sehingga mampu mendorong berkembangnya pemikiran kritis siswa dalam pembelajaran (Ploetzner \& Schlag, 2013). Strategi pembelajaran ekspositori lebih menekankan kepada proses penyampaian materi secara verbal dari seorang guru kepada 
sekelompok siswa dengan maksud agar siswa dapat menguasai materi pelajaran secara optimal. Dalam sistem ini, guru menyajikan bahan dalam bentuk yang telah dipersiapkan secara rapi, sistematik dan lengkap sehingga siswa tinggal menyimak dan mencernanya secara teratur dan tertib. Tujuan utama seorang guru dalam mewujudkan tujuan pendidikan di sekolah adalah mengembangkan strategi pembelajaran yang efektif. Penelitian ini bertujuan untuk menganalisis strategi pembelajaran ekspositori dalam praktik pembelajaran IPS di tingkat SMP.

\section{METODE}

Tipe penelitian yang digunakan adalah bersifat deskriptif, yaitu untuk menggambarkan kejadian, peristiwa pada saat pembelajaran sehingga meningkatkan mutu dan kualitas belajar siswa di mana guru dengan peneliti, guru sebagai pembimbing dalam melakukan proses pembelajaran sedangkan peneliti sebagai pengamat saat berlangsungnya proses pembelajaran.

\section{Desain Penelitian}

Peneliti bertindak sebagai instrumen utama sekaligus pengumpul data, perencana, pelaksana, menganalisis, dan pelapor hasil penenelitian. Dalam penelitian ini juga menggunakan instrumen lain sebagai pendukung sesuai dengan metode penggumpulan data, kehadiran peneliti sangatlah penting karena peneliti bertindak sebagai pengamat dan pewawancara. Sebagai pengamat, peneliti selalu mengamati setiap aktivitas dalam kelas selama pembelajaran berlangsung, peneliti juga bertindak sebagai pembuat laporan hasil penelitian.

\section{Populasi dan Sampel Penelitian}

Subjek penelitian ini adalah siswa kelas VIII di SMP Negeri 9 Leihitu Satap. Jumlah siswa sebanyak 28 siswa, yang terdiri dari 12 siswa perempuan dan 16 siswa laki-laki. Sumber data yang dimaksud dalam penelitian ini adalah subjek dari mana data tersebut dapat diperoleh. Diperlukan adanya sumber-sumber yang dapat memberikan keterangan yang berkaitan dengan data yang dibutuhkan dalam penelitian ini, sedangkan jenis data dalam penelitian ini yaitu data primer. Data primer adalah data yang langsung dikumpulkan oleh peneliti dari sumber pertama. Apabila peneliti menggunakan wawancara dalam penggumpulan data, maka sumber data tersebut adalah responden yaitu orang yang merespon atau menjawab pertanyaan peneliti. Dalam data ini di ambil dari sumber-sumber data wawancara dari guru dan siswa mengenai pelaksanaan strategi pembelajaran ekspositori dalam mata pelajaran IPS yang dikembangkan, serta mengenai fasilitas yang digunakan.

\section{Teknik Pengumpulan Data}

Observasi adalah suatu teknik operasional merupakan data melalui proses pencatatan yang diamati secara langsung. Observasi merupakan teknik pengumpulan data, dimana melakukan pengamatan secara langsung ke objek penelitian untuk melihat dari dekat kegiatan yang dilakukan. Teknik pengambilan data yang digunakan dengan lembar observasi ini untuk mengetahui implementasi penggunaan strategi pembelajaran langsung oleh guru dalam proses pembelajaran dikelas. Teknik dokumentasi adalah cara pengumpulan data melalui peninggalan tertulis, seperti arsip-arsip dan termasuk juga buku-buku tentang pendapat, teori, dalil, atau hukum-hukum dan lainnya yang berkaitan dengan masalah penelitian. Metode dokumentasi digunakan untuk memperoleh hasil 
pengamatan tentang pelaksanaan strategi pembelajaran ekspositori pada mata pelajaran IPS di SMP Negeri 9 Leihitu Satap. Wawancara adalah percakapan dengan maksud tertentu. Percakapan dilakukan oleh dua belah pihak, di mana pewawancara yang mengajukan pertanyaan dan yang diwawancarai yang memberikan jawaban atas pertanyaan itu atau wawancara berjalan menurut kondisi.

\section{Teknik Analisis Data}

Analisis data pada dasarnya untuk memilih, menentukan dan menggolongkan data untuk menjawab hal pokok dalam penelitian ini. Didalam penelitian ini dapat menentukan beberapa kategori yaitu: 1) dengan kriteria kurang baik, 2) dengan kriteria cukup baik, 3) dengan kriteria baik, 4) dengan kriteria sangat baik. Analisis data merupakan upaya penetaan secara sistematis catatan hasil observasi, wawancara dan dokumentasi untuk meningkatkan pemahaman peneliti tentang pelaksanaan strategi pembelajaran ekspositori pada guru IPS di SMP Negeri 9 Leihitu Satap.

\section{HASIL DAN PEMBAHASAN}

1. Hasil Observasi

Data hasil observasi tentang penggunaan strategi pembelajaran ekspositori yang diimplementasikan oleh guru IPA pada SMP Negeri 9 Leihitu Satap ditampilkan pada Tabel 1.

Tabel 1. Data Hasil Observasi tentang Penggunaan Strategi Pembelajaran Ekspositori

\begin{tabular}{|c|c|c|}
\hline Aspek Pembelajaran & Aspek Yang Diamati & Penilaian \\
\hline \multirow{3}{*}{ Kegiatan Pendahuluan } & $\begin{array}{l}\text { Guru memulai kegiatan dengan absensi } \\
\text { dan doa }\end{array}$ & 4 \\
\hline & $\begin{array}{l}\text { Guru mengecek kesiapan, perlengkapan } \\
\text { dan peralatan yang diperlukan. }\end{array}$ & 1 \\
\hline & $\begin{array}{l}\text { Guru menyampaikan } \mathrm{SK}, \mathrm{KD} \text {, tujuan } \\
\text { pembelajaran. }\end{array}$ & 4 \\
\hline \multirow{3}{*}{ Langkah Persiapan } & Persiapan guru dalam menyampaikan & 4 \\
\hline & Membangkitkan & 4 \\
\hline & Penguasaan bahan pembelajaran & 4 \\
\hline \multirow{3}{*}{ Langkah Penyajian } & Intonasi suara & 3 \\
\hline & Kejelasan kalimat dan bahasa & 3 \\
\hline & Kontak pandang dan perhatian guru & 4 \\
\hline \multirow{3}{*}{ Langkah Korelasi } & Meningkatkan & 4 \\
\hline & Menghubungkan & 3 \\
\hline & $\begin{array}{l}\text { Mendorong siswa untuk berfikir kritis dan } \\
\text { rasional }\end{array}$ & 3 \\
\hline \multirow[b]{2}{*}{ Langkah Menyimpulkan } & Menyimpulkan & 4 \\
\hline & $\begin{array}{l}\text { Memberikan penguatan atau keyakinan } \\
\text { pada siswa }\end{array}$ & 2 \\
\hline \multirow[t]{2}{*}{ Langkah Pengaplikasian } & Memberi pertanyaan kepada siswa & 4 \\
\hline & Memberi tugas yang relavan pada siswa & 4 \\
\hline \multirow{3}{*}{ Kegiatan Penutup } & $\begin{array}{l}\text { Guru meminta siswa menyimpulkan } \\
\text { materi yang telah dipelajari }\end{array}$ & 1 \\
\hline & $\begin{array}{l}\text { Guru melakukan penilaian pembelajaran } \\
\text { saat melakukan tanya jawab }\end{array}$ & 4 \\
\hline & $\begin{array}{l}\text { Guru mengakhiri kegiatan belajar dengan } \\
\text { memberikan pesan untuk tetap belajar } \\
\text { tentang materi selanjutnya. }\end{array}$ & 4 \\
\hline
\end{tabular}


Berkaitan dengan penggunaan strategi ekspositori dalam pembelajaran, ada beberapa hal yang harus dipahami oleh guru IPS di SMP Negeri 9 Leihitu Satap dan juga setiap guru yang akan menggunakan strategi ekspositori, pertama yaitu: guru harus mampu merumuskan tujuan dalam bentuk perubahan tingkah laku yang spesifik yang berorientasi kepada hasil belajar. Kedua, guru harus memiliki penguasaan materi pelajaran dengan baik. Penguasaan materi yang sempurna, akan membuat kepercayaan diri guru meningkat, sehingga guru akan mudah mengurus kelas. Ketiga, guru harus memiliki pengenalan yang baik terhadap kondisi kelas agar guru dapat mengantisipasi berbagai kemungkinan yang dapat mengganggu proses penyajian materi pelajaran. Selain itu, agar dapat berjalan dengan efektif dan mencapai hasil yang optimal, strategi ekspositori juga harus diterapkan dengan prosedur atau tata cara yang tepat.

Berdasarkan pembahasan hasil penelitian pada di SMP Negeri 9 Leihitu Satap pada Guru IPS menunjukkan bahwa penggunaan strategi pembelajaran ekspositori diterapkan dengan prosedur atau langkah-langkah sebagai berikut.

\section{a) Langkah Kesiapan}

Dari hasil pengamatan yang diamati, pada langkah kesiapan yang dilakukan oleh guru di SMP Negeri 9 Leihitu Satap sudah dapat diterapkan dengan baik. Di mana, materi yang akan disampaikan oleh guru kepada siswa sudah siap disajikan karena dalam materi tersebut sudah disiapkan secara rinci dan jelas. Didalam proses belajar mengajar, guru menjelaskan materi itu dengan jelas dan menarik sehingga motivasi dan minat belajar siswa bertambah dalam menerima pelajaran kemudian guru juga membimbing siswa untuk mencatat hal-hal penting dalam materi tersebut supaya siswa dapat menguasai materi itu dengan baik.

\section{b) Langkah Penyajian}

Langkah penyajian yaitu langkah penyampaian materi. Di dalam penyampaian materi, intonasi suara yang dilakukan oleh guru itu sudah jelas dan menarik didengar oleh siswa. Pada saat menjelaskan materi, guru selalu melakukan suara tekanan pada saat tertentu seperti kejelasan kalimat dan bahasa pada saat mengucapkan kata yang sangat bermakna atau kata inti dari materi yang dijelaskan sehingga siswa dapat menerima pelajaran dengan baik serta kontak pandang dan perhatian guru itu mengarah ke siswa untuk mengetahui kemampuan siswa dalam menerima pelajaran yang diberikan.

\section{c) Langkah Korelasi}

Langkah korelasi yaitu langkah menghubungkan materi pelajaran dengan pengalaman masing-masing siswa. Pada langkah ini, guru mencoba untuk menguji kemampuan siswa dan mendorong mereka berpikir dengan meminta siswa maju di depan kelas untuk menceritakan pengalaman yang pernah siswa alami dengan menghubungkan keterkaitan materi yang telah diajarkan. Hasil observasi menunjukkan bahwa ternyata ada beberapa siswa saja yang mampu mengaitkan antara materi dengan pengalaman yang mereka alami.

\section{d) Langkah Menyimpulkan}

Menyimpulkan adalah harapan untuk memahami inti dari materi yang telah disajikan. pada dalam langkah ini, guru memberikan penguatan atau keyakinan kepada siswa untuk menyimpulkan inti/sari dari materi yang disajikan dengan kata-kata mereka 
sendiri. Dengan begitu, mereka akan mudah mengerti dan mudah dalam menerapkannya sesuai dengan apa yang dipahami oleh masing-masing siswa itu sendiri. Hasil pengamatan penulis terlihat bahwa guru meminta beberapa siswa untuk menyimpulkan materi yang telah disajikan dengan kata-kata mereka sendiri, ternyata mereka bisa menyimpulkan materi pelajaran dengan baik.

\section{e) Langkah Aplikasi}

Langkah aplikasi adalah langkah unjuk kemampuan siswa setelah mereka menyimak penjelasan guru. Dalam langkah ini, guru mengevaluasi kemampuan siswa melalui tanya jawab dengan tujuan unjuk menguji kemampuan siswa. Guru juga memberikan pertanyaan kepada siswa dengan materi yang diajarkan untuk mengetahui sampai dimana pemahaman yang dimiliki oleh siswa dalam proses pembelajaran. Hasil observasi menunjukkan bahwa ada beberapa siswa yang kurang mampu memahami materi yang diberikan oleh guru sehingga mereka memberikan jawaban yang kurang memuaskan. Dengan demikian guru perlu memberikan tugas yang relevan dari materi yang diajarkan agar siswa mampu menerapkannya kembali.

Berdasarkan hasil observasi yang telah dilakukan di SMP Negeri 9 Leihitu Satap tepatnya di kelas VIII bahwa pada langkah kesiapan yang dilakukan oleh guru sudah diterapkan dengan sangat baik sehingga motivasi dan minat belajar siswa bertambah dalam menerima pelajaran. Langkah penyajian juga dilakukan dengan baik dan maksimal, di mana guru penyampaikan materi dengan intonasi suara yang jelas dan menarik sehingga siswa dapat menerima pelajaran dengan baik. Langkah korelasi sudah diterapkan dengan baik, di mana guru sudah menguji kemampuan siswa untuk mendorong siswa berpikir dalam suatu pengalaman dikaitkan dengan materi yang telah diajarkan. Langkah menyimpulkan juga sudah dilakukan dengan baik di mana guru membimbing siswa dalam menyimpulkan inti/sari dari materi yang disajikan. Terakhir, langkah pengaplikasian juga sudah diterapkan dengan baik di mana guru menguji kemampuan siswa melalui tanya jawab.

\section{Hasil Wawancara}

Hasil wawancara dengan salah satu guru mata pelajaran IPS tentang persepsinya tentang tugas dan fungsi guru dalam pembelajaran sebagai berikut.

Guru adalah tenaga pendidik yang memberikan sejumlah ilmu pengetahuan kepada siswa di sekolah. Tugas utama pendidik profesional yaitu mendidik, mengajar, membimbing, melatih, dan menilai peserta didik dalam proses pembelajaran. Oleh karena itu guru harus berperan aktif dalam menyampaikan materi pelajaran.

Dalam melaksanakan kegiatan belajar mengajar, perlu peran guru untuk melatih kemampuan siswa melalui tanya jawab, dimana guru harus menciptakan suasana belajar yang nyaman dan menjaga kelas yang baik agar tetap kondusif untuk terjadinya proses belajar bagi seluruh siswa sehingga proses belajar dengan melakukan tanya jawab dapat berhasil dengan baik.

Sebagai fasilitator, guru berperan dalam memberikan pelayanan untuk memudahkan siswa dalam kegiatan pembelajaran. Dalam kegiatan pembelajaran guru dituntut untuk mampu mengorganisasikan berbagai jenis media serta dapat memanfaatkan berbagai sumber belajar. Selain itu, guru dituntut untuk mempunyai kemampuan dalam berkomunikasi dan berinteraksi dengan siswa.

Selain wawancara dengan guru mata pelajaran, peneliti juga melakukan 
wawancara dengan beberapa siswa. Namun pendapat mereka kurang sesuai dengan apa yang sudah diteliti atau diobservasi langsung di dalam kelas. Menurut pendapat beberapa siswa, dalam proses belajar mengajar guru menyampaikan materi dengan jelas dan menarik, namun guru kurang memberi kesempatan untuk menguji kemampuan siswa menyangkut materi yang diajarkan sehingga siswa cenderung bermain pada saat proses belajar mengajar, oleh karena itu mereka mengharapkan guru harus melatih kemampuan siswa dengan materi pelajaran agar mereka dapat memahami materi pelajaran dengan baik dan jelas.

Berdasarkan hasil ini, dibuktikan bahwa proses pembelajaran dengan menggunakan strategi pembelajaran ekspositori sudah diterapkan dengan baik. Dimulai dengan adanya persiapan pembelajaran oleh guru dan siswa. Guru menyiapkan materi dan menyajikannya dengan baik, siswapun dapat menerima pelajaran tersebut sehingga kemampuan dan minat belajar siswa bertambah dalam menerima materi yang diajarkan. Selain itu dalam proses pembelajaran terjalin suasana yang sangat kondusif dan menyenangkan.

\section{KESIMPULAN}

Berdasarkan hasil penelitian dan pembahasan yang dilakukan di SMP Negeri 9 Leihitu Satap tentang pembelajaran ekspositori, maka kesimpulan dari penelitian ini adalag bahwa kegiatan pembelajaran ekspositori sangat berperang penting dilakukan dalam proses pembelajaran. Motivasi dan minat belajar siswa meningkat ketika menerima materi yang diberikan oleh guru dan alhasilnya proses pembelajaran berjalan dengan baik sesuai dengan tujuan pembelajaran. Selain itu guru juga mampu mendorong siswa untuk berpikir kritis dan rasional terkait materi yang diberikan sehingga siswa mampu menyimpulkan intisari dari materi yang telah dipelajari.

\section{REFERENSI}

Cenoz, J. (2012). Bilingual educational policy in higher education in the Basque Country. Language, Culture and Curriculum, 25(1), 41-55. https://doi.org/10.1080/07908318.2011.653057.

Darling-hammond, L., Flook, L., Cook-harvey, C., Barron, B., Flook, L., Cook-harvey, C., ... Barron, B. (2019). Implications for educational practice of the science of learning and development. Applied Developmental Science, O(0), 1-44. https://doi.org/10.1080/10888691.2018.1537791.

Ellerani, P., \& Gentile, M. (2013). The Role of Teachers as Facilitators to Develop Empowering Leadership and School Communities Supported by the Method of Cooperative Learning. Procedia Social and Behavioral Sciences, 93, 12-17. https://doi.org/10.1016/j.sbspro.2013.09.144.

Ferguson, H. B., Bovaird, S., \& Mueller, M. P. (2007). The impact of poverty on educational outcomes for children. Paediatrics and Child Health, 12(8), 701-706. https://doi.org/10.1093/pch/12.8.701.

Gbollie, C., \& Keamu, H. P. (2017). Student Academic Performance: The Role of Motivation, Strategies, and Perceived Factors Hindering Liberian Junior and Senior High School Students Learning. Education Research International, 2017, 1-11. https://doi.org/10.1155/2017/1789084.

Genlott, A. A., \& Grönlund, Å. (2013). Improving literacy skills through learning reading by writing: The iWTR method presented and tested. Computers and Education, 67, 98-104. https://doi.org/10.1016/j.compedu.2013.03.007.

Hammond, C. D. (2016). Internationalization, nationalism, and global competitiveness: a comparison of approaches to higher education in China and Japan. Asia Pacific Education Review, 17(4), 555566. https://doi.org/10.1007/s12564-016-9459-0

Leung, M. Y., \& Wang, Z. (2006). Impact of school facilities on working behavior of teachers. International Journal of Strategic Property Management, 10(2), 79-91. https://doi.org/10.1080/1648715X.2006.9637546.

Ploetzner, R., \& Schlag, S. (2013). Strategic learning from expository animations: Short- and mid-term effects. Computers and Education, 69, 159-168. https://doi.org/10.1016/j.compedu.2013.07.013. 
60 | Jurnal Pendidikan Profesi Guru Indonesia, Vol. 1, No. 1, pp. 53-60, February 2021

Post, L. S., Guo, P., Saab, N., \& Admiraal, W. (2019). Effects of remote labs on cognitive, behavioral, and affective learning outcomes in higher education. Computers and Education, 140(May). https://doi.org/10.1016/j.compedu.2019.103596.

Ritter, S. M., \& Mostert, N. (2017). Enhancement of Creative Thinking Skills Using a Cognitive-Based Creativity Training. Journal of Cognitive Enhancement, 1(3), 243-253. https://doi.org/10.1007/s41465-016-0002-3.

Schaap, H., Baartman, L., \& de Bruijn, E. (2012). Students' Learning Processes during School-Based Learning and Workplace Learning in Vocational Education: A Review. Vocations and Learning, 5(2), 99-117. https://doi.org/10.1007/s12186-011-9069-2.

Schneider, R., \& Sparfeldt, J. R. (2020). Academic competence and affect self-concepts in elementary school students: Social and dimensional comparisons. Social Psychology of Education, 23(1), 233257. https://doi.org/10.1007/s11218-019-09532-3.

Sukanti, S., Sumarsih, S., Siswanto, S., \& Widayati, A. (2008). Persepsi Mahasiswa Program Studi Pendidikan Akuntansi Fise Uny Terhadap Profesionalitas Guru Berdasarkan Undangundang Guru Dan Dosen No 14 Tahun 2005. Jurnal Pendidikan Akuntansi Indonesia, 6(2), $70-81$. https://doi.org/10.21831/jpai.v6i2.935. 